\title{
Synthesis, characterization and applications of chitosan based metallic nanoparticles: A review
}

\section{Devendra Kumar Verma}

Department of Chemistry, Sri Venkateswara College, University of Delhi (South Campus), Delhi, India

\section{Rajdeep Malik}

Department of Chemistry, Gurukul Kangri (Deemed to be University) Haridwar-249404 (Uttarakhand), India

\section{Jagram Meena*}

Department of Chemistry, Gurukul Kangri (Deemed to be University) Haridwar-249404 (Uttarakhand), India

\section{Rashmi Rameshwari}

Department of Biotechnology, Manav Rachna International Institute of Research and Studies, Faridabad (Haryana), India

${ }^{*}$ Corresponding author. Email: jagram.meena@gkv.ac.in

\section{Article Info}

https://doi.org/10.31018/ jans.v13i2.2635

Received: March 27, 2021

Revised: May 12, 2021

Accepted: May 19, 2021

\section{How to Cite}

Verma, D.K. et al. (2021). Synthesis, characterization and applications of chitosan based metallic nanoparticles: A review. Journal of Applied and Natural Science, 13(2), 544 - 551. https://doi.org/10.31018/jans.v13i2.2635

\begin{abstract}
Chitosan as a natural biopolymer has been produced to be the important host for the preparation of metallic nanoparticles (MNPs) because of its excellent characteristics like:- good stabilizing and capping ability, biocompatibility, biodegradability, ecofriendly and non-toxicity properties. Chitosan can play a very important role for synthesis of metallic nanoparticles, as chitosan is a cationic polymer. It attracts metal ions and reduces them and also Capps and stabilizes. So basically chitosan can be responsible for the controlled synthesis of metallic nanoparticle. Chitosan has a very good chelating property. This property is due to its $-\mathrm{NH}_{2}$ and $-\mathrm{OH}$ functional groups. Size and shape of metallic nanoparticles are much affected by chitosan concentration, molecular weight, time of reaction, degree of acetylation of chitosan, $\mathrm{pH}$ of the medium, method of synthesis and type of derivative of chitosan etc. Metallic nanoparticles`s properties and applications are much associated with their size and shape. Optimization of the metallic nanoparticle size and shape has been the subject of curiosity for nanotechnology scientist. Chitosan can solve this problem by applying the optimization conditions. But a very little work is reported about: - how chitosan can affect the size and shape of metallic nanoparticles and how can it reduce metal salts to prepare metallic nanoparticle, stablilized in chitosan metrics. This is very first report as a review article highlighting the effect of chitosan on synthesis of metallic nanoparticles and optimization conditions. This review will also be beneficial for scientist working on food sensing application of nanoparticles. Various synthesis methods and applications of chitosan based metallic nanoparticles have also been reported in details.
\end{abstract}

Keywords: Chitosan, Cationic polymer, Metallic nanoparticles (MNPs), Nanotechnology, Synthesis

\section{INTRODUCTION}

Size and shape of the nanoparticles are one of the very important properties of metallic nanoparticles. Applications of metallic nanoparticles are decided on the basis of size, shape and the method of synthesis of nanoparticles. So to optimize the conditions for controlled synthesis of any metallic nanoparticle has always been the topic of curiosity between nanotechnology scientists. All metallic nanoparticles (MNPs) are especially attractive owing to their unique properties and applications
(Huang et al., 2008). It has been accepted that the size, morphology, dispensability and physicochemical properties of MNPs are strongly associated with their applications, which are affected by the synthesized approach (Sengupta et al., 2004). Chitosan is a biopolymer synthesised from marine crustacean shells. However, commercially available chitosan is produced from deacetylation of chitin, which is a natural biopolymer found in crab, coral shrimp, mushroom lobster, jellyfish, butterfly, ladybug and fungi (Potara et al., 2009, Lupusoru et al., 2017). Chitosan is a cationic polymer 
composed of randomly distributed $\mathrm{N}$-acetyl glucosamine and D-glucosamine, containing in composition, sequence, and molecular chain length (Fig.1).

The degree of acetylation of chitosan is characterized by the molar fraction of $\mathrm{N}$-acetylated units (DA) or as a percentage of acetylation (DA \%). Different methods for conversion of chitin to chitosan like Chemical Extraction (Chemical Deproteinization, Chemical Demineralization),Biological Extraction of Chitin, Enzymatic Deproteinization, Fermentation Chemical Deacetylation, (Younes et al., 2015) have been used. Chitosan enables the electrostatic interaction with negatively charged biopolymer and the interaction with cell membranes. Chitosan has been developed in diverse forms like films, foams, (Lin et al., 2009, Marpu and Benton 2018, Kumar et al., 2017) fibers, (Wang et al., 2017a) hydrogel and nanoparticles (Thirumavalavan et al., 2013). Chitosan forms inter- and intra-molecular hydrogen bonding owing to amine and hydroxyl groups. Therefore, it has a rigid crystalline structure (Khedri et al., 2018). Incorporation of metallic nanoparticles in chitosan increases its application on huge scale. Some of the applications included are in catalysis, nonlinear optics, adsorptions, heavy metal ion sensing, environmental remediation, antimicrobial activity, catalytic activity, removal of dye, antioxidant, drug delivery, bio imaging, anti-cancer activity, Sensing and wound healing (Ahmad et al., 2011, Sannegowda et al., 2015, Liu et al., 2017, Misra et al., 2016, Akbari-Sharbaf et al., 2015) (Fig. 2).

This review is focused on two major topics mainly. First is the synthesis, characterization, and applications of chitosan-based metallic nanoparticles/ nanocomposites and the second is the effect of chitosan on the size and shape of metallic nanoparticles.

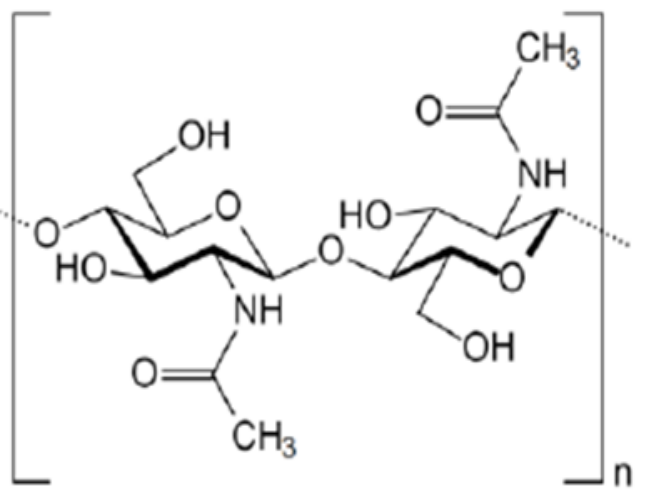

Chitin

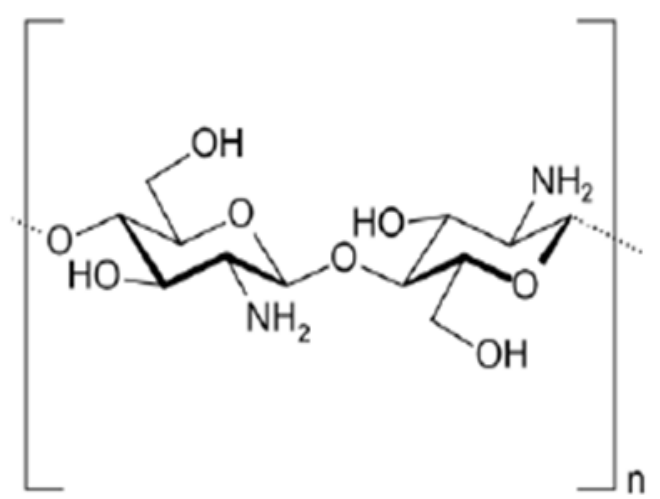

Chitosan

Fig.1. Chitin and Chitosan structure (Younes \& Rinaudo, 2015).

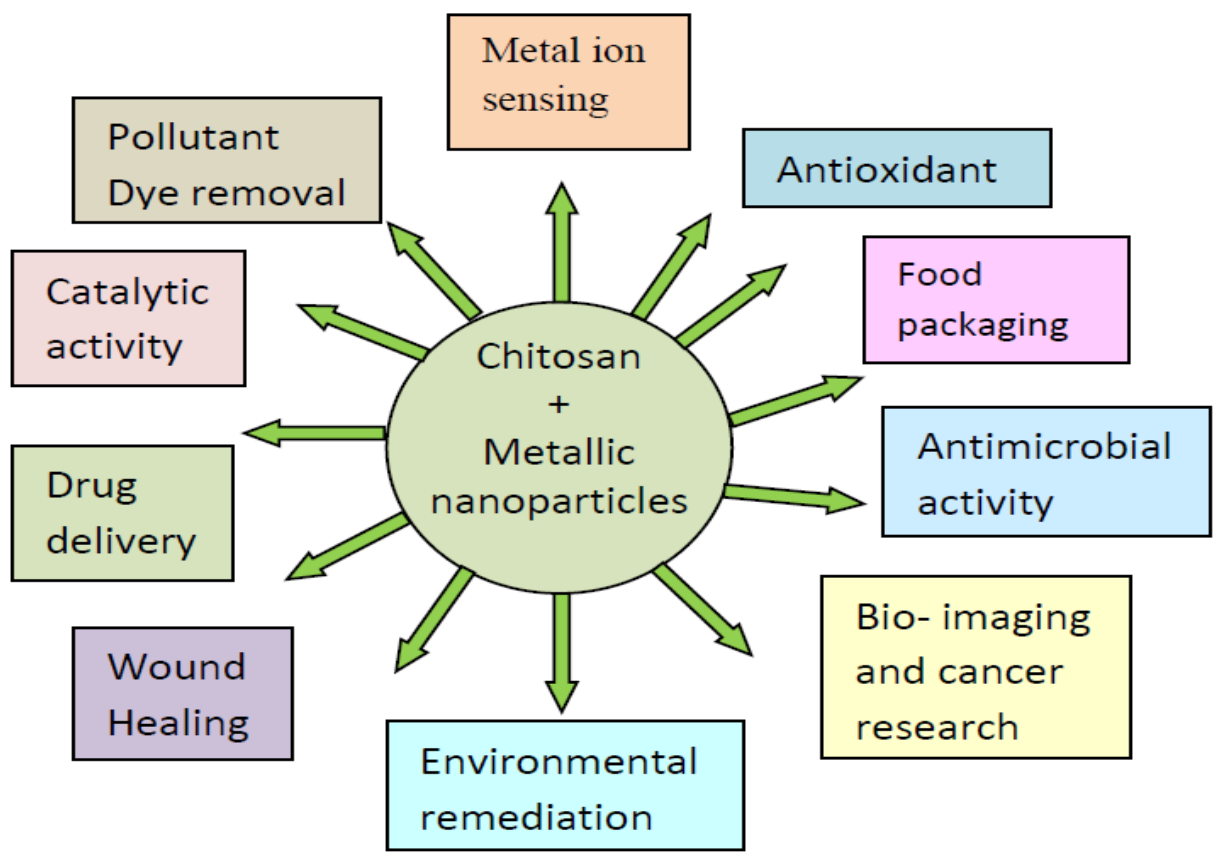

Fig 2. Applications of chitosan based metallic nanoparticle. 
Verma, D.K. et al. / J. Appl. \& Nat. Sci. 13(2), 544 - 551 (2021)

\section{PREPARATION AND CHARACTERIZATION}

Preparation of chitosan based metallic nanoparticles Inanocomposites

Chitosan based metallic nanocomposites have been synthesized by various methods for different metal nanoparticles ( $\mathrm{Fe}, \mathrm{Cu}, \mathrm{Au}, \mathrm{Ag}, \mathrm{Zn}, \mathrm{V}, \mathrm{Ti}, \mathrm{Cr}, \mathrm{Ni}, \mathrm{Co}$ etc.) (Table 1). Some of the important methods for biopolymer chitosan based metallic nanoparticle preparation inclues; co-precipitations, green synthesis, in-situ precipitations, ex-situ precipitations and hydrothermal method etc. Chitosan (CS) is important for metallic nanoparticles synthesis because it works like a capping as well as a reducing agent. Chitosan as a cation, it also makes complex with anions to make nanocomposites and nanoparticles. CS-stabilized Au nanoparticles were synthesized in the absence of a reducing agent (Vo et al., 2014). Stabilization of $\mathrm{Au}$ and $\mathrm{Ag}$ nanoparticles within CS Adopting/demonstrating green synthesis method for making AuNPs and AgNPs has been studied (Sanpui et al., 2008). It has been found that size and stability of metallic nanoparticles also depend on chitosan molecular weight and concentration. Chitosan-coated AuNPs were synthesized and analyzed for the stability of the different size of AuNPs with respect to CS-molecular weight and concentration (Lupusoru et al., 2017). CSstabilized AuNPs were prepared in the presence of Thiamine pyrophosphate (TPP) to see the effect of Chitosan (CS) concentration on the size and shape of AuNPs without any additional reducing agents. CS- capped AuNPs have been used in the sensing ability of heavy metal ions based on SPR changes. Au-CS nanocomposites were found suitable for using selective electrochemical sensors to determine antioxidants and determination of polyphenol index in wines (Sanpui, et al., 2008). Copper-Chitosan Nanoparticles were synthesized by green method and further studied its Antibacterial Activity (Manikandan \& Sathiyabama et al., 2015). Preparations of Magnetic Chitosan nanoparticles support for Cellulase immobilization. The immobilized cellulase retained $50 \%$ of its initial activity after 10 cycles (Zang et al., 2014). Chitosan-titanium oxide fibers and zero-valent nanoparticles were prepared by hydrothermal method (Ali et al., 2018). Zinc encapsulated chitosan NPs were prepared to promote maize crop yield(Chaudhary et al., 2019). In-situ method has been found the most famous and easiest method for formation of chitosan based metallic nanocomposites. Nickel-chitosan nanocomposite coated cellulose filter paper was synthesized using the in-situ method (Kamal et al., 2016). Chromium-loaded Chitosan Nanocomposites were also synthesized by in-situ method (Chattopadhyay, et al., 2014). Different methods and metallic nanocomposites synthesized using chitosan as a biopolymer as capping and complexing agent are shown in Table 1.

\section{Characterization of chitosan based metallic (CS-M) nanoparticles}

Various techniques have been explored to analysis the

Table 1. Various methods used for the synthesis of chitosan based metallic nanoparticles/nanocomposites.

\begin{tabular}{|c|c|c|c|c|c|}
\hline $\begin{array}{l}\text { S. } \\
\text { No }\end{array}$ & Biopolymer & Metal & Method & Characterization & Reference \\
\hline 1 & Chitosan & $\mathrm{Au}$ & Complex formations & $\begin{array}{l}\text { Potentiometry, electronic spec- } \\
\text { troscopy and X-ray absorption } \\
\text { spectroscopy (XAS) }\end{array}$ & (Vo et al., 2014) \\
\hline 2 & Chitosan & $\mathrm{Ag \backslash Au}$ & Green synthesis & SEM,UV & (Sanpui et al., 2008) \\
\hline 3 & Chitosan & $\mathrm{Cu}$ & Green synthesis & SEM, XRD,TEM FTIR,VSM & $\begin{array}{l}\text { (Manikandan and } \\
\text { Sathiyabama 2015) }\end{array}$ \\
\hline 4 & Chitosan & $\mathrm{Fe}$ & Co-precipitations & $\begin{array}{l}\text { FTIR, Vibrating-sample magne- } \\
\text { tometer (VSM), DLS, } \\
\text { SEM,TEM, XRD, UV }\end{array}$ & (Dung et al., 2009) \\
\hline 8 & Chitosan & $\mathrm{Pd}$ & Hydrothermal method & FTIR, SEM, XRD,VSM & (Baran 2020) \\
\hline 9 & Chitosan & $\mathrm{TiO}_{2}$ & in-situ method & FTIR, XRD, FESEM, & (Ali et al., 2018) \\
\hline 10 & Chitosan & $\mathrm{Zn}$ & in-situ method & FTIR, SEM, DLS, XRD & (Choudhary et al., 2019) \\
\hline 11 & Chitosan & $\mathrm{Ni}$ & in- situ method & FESEM, XRD, FTIR, UV & (Kamal et al., 2016) \\
\hline 12 & Chitosan & Co & - & XRD, FTIR, SEM & $\begin{array}{l}\text { (Chattopadhyay et al., } \\
\text { 2014) }\end{array}$ \\
\hline 13 & Chitosan & $\mathrm{Cr}$ & Suspensions method & SEM & (Tahir et al., 2019) \\
\hline 14 & Chitosan & V & $\begin{array}{l}\text { adsorption/ } \\
\text { desorption method }\end{array}$ & $\mathrm{pH}$ & (Guzman et al., 2002) \\
\hline 15 & Chitosan & $\begin{array}{l}\mathrm{Ag}, \mathrm{Au} \\
\mathrm{Pt}, \mathrm{Cu}\end{array}$ & Chemical Reductions & $\begin{array}{l}\text { TEM, FTIR, UV-Vis spectrome- } \\
\text { ter }\end{array}$ & (León et al., 2017) \\
\hline
\end{tabular}


structure and spectroscopic characteristics of natural chitosan based metallic nanoparticles in the literature. Some of the characterization techniques are X-ray diffractions, visible sample magnetizations, scanning electron microscope, transmissions electron microscope, Dynamic light scattering, particles size analyser, etc.

\section{Effect of chitosan on synthesis and optimization of metallic nanoparticles}

Metallic nanoparticles properties are much affected by their size and shape. These properties decide the application of metallic nanoparticles in various fields. Chitosan plays an important role in deciding the size and shape of metallic nanoparticles. The positive charge on chitosan makes it suitable to be used as core shell for nanoparticles and covering metallic particles. Chitosan possesses $-\mathrm{OH}$ and $-\mathrm{NH}_{2}$ groups. These groups are responsible for the chelating property of chitosan. A chemical bond is developed between chitosan and $\mathrm{Ag}^{+}$ ion. This has been confirmed experimentally by FTIR and NMR spectroscopy (Modrzejewska et al., 2009). So chitosan has been used as a reducing and capping agent in synthesis of metallic nanoparticles. Gold, silver, copper, iron and other transition metal series element nanoparticles have been synthesised by using chitosan as a reducing and capping agent (Pestova et al., 2005). Usually, metal salt is used as precursor, chitosan as reducing and capping agent. Chitosan is used in a range of (1-2) \% solution in acidic or basic medium. The amount of the chitosan affect the size and shape of metallic nanoparticles a lot.

The size and shape of the metallic nanoparticles reduced and stabilized by chitosan are affected by many factors: 1. Degree of chitosan deacetylation, 2. molecular weight, 3. reaction time, 4. concentration, 5. Temperature of the reaction and $\mathrm{pH}$ of the solution (AbricaGonzález et al., 2019). The time of capping of Au nanoparticles with chitosan decides the colour of the solution corresponding to the size of Au nanoparticles. The intensity of the Au nanoparticles decides the shape of nanoparticles which is affected by the capping time duration. Chitosan stabilized Au nanoparticles are used in food sensing application (Javed et al., 2020). Chitosan and its derivative have different effect on the size and shape of nanoparticles. Generally, on increasing the chitosan concentration metallic nanoparticle size increases but in case of carboxymethyl guar gum on increasing the carboxymethyl chitosan concentration the size of $\mathrm{Fe}_{3} \mathrm{O}_{4}$ nanoparticles decreases. This may be due to more amount of carxboxymethylchitosan stabilizes more metallic nanoparticles. Sonication time was studied from 30 to 60 minutes for coating of $\mathrm{Fe}_{3} \mathrm{O}_{4}$ nanoparticles by chitosan. It was found that on increasing time of sonication size of nanoparticles decreases, but increasing further time can remove the capping of chi- tosan. Effect of temperature was also studied in this case. It was found that on increasing temperature from (25 to 50 and 80 ) ${ }^{\circ} \mathrm{C}$, the size of $\mathrm{Fe}_{3} \mathrm{O}_{4}$ nanoparticles decreases (Zeinali et al., 2016). Ag nanoparticles have been synthesized by chitosan using different molecular weight. Ag Nanoparticle size was found decreased with increasing in stirrer speed and decrease in temperature from (25 to 4) ${ }^{\circ} \mathrm{C}$. The UV spectrum of Ag- chitosan nanoparticles shows that a broad peak spectrum is obtained on increasing the molecular weight. This explains that on increasing the higher molecular weight of chitosan a range of size of $\mathrm{Ag}$ nanoparticles is obtained. But on decreasing the molecular weight of chitosan small Ag nanoparticles of the small range of nanoparticles are obtained. The best antimicrobial activities of Ag nanoparticles are obtained smallest size corresponds to smallest molecular weight of chitosan (Honary et al., 2011).

\section{APPLICATIONS OF METALLIC CHITOSAN NANO- PARTICLE}

\section{Metal removal by chitosan metallic nanoparticles}

Chitosan metallic nanoparticles are being used in metal removal from waste water treatment by the adsorptions batch method. In this process first, chitosan based metallic nanoparitcle is synthesized by in-situ or ex-situ methods. Then such made nanoparticles solutions are used to make films by solution casting method. These films are dried in Teflon or plastic plate or boxes. Then these films are cut in fixed dimensions and then dipped in different concentration stock solution of metals. To check the effect of metal and chitosan concentration on adsorption, optimum conditions are applied. Cr (IV) was removed by adsorption technique using chitosan based magnetic nanoparticles. Optimum conditions were applied to see the effect of $\mathrm{pH}$ and time of adsorption (Zimmermann et al., 2010). In most cases, it has been found that an increase in the ratio of chitosan and biopolymer concentration increases the adsorption of heavy metals (Al-Sayed et al., 2019). $\mathrm{Fe}_{3} \mathrm{O}_{4}-\mathrm{C} 18-$ chitosan-DETA (FCCD) particles were used in the removal of $\mathrm{Dy}^{3+}, \mathrm{Nd}^{3+}$, and $\mathrm{Er}^{3+}$ at $25^{\circ} \mathrm{C}$ and $7 \mathrm{pH}$ of the medium. These nanoparticles were synthesized by the surface deposition-stepwise grafting method successfully (Liu, E et al., 2017). Kinetics data was used to calculate the order of the adsorption reaction, it was found a pseudo-second-order reaction, and the Langmuir equation fitted well to the adsorption isotherms. A comparative study was done to see the effect of chitosan on metallic nanopartical for the adsoption of $\mathrm{Pb}$ (II) and $\mathrm{Cd}$ (II). Very fine results were obtained. Pb (II) and Cd (II) were removed maximum up to $(79.24$ and 36.42$) \mathrm{mg} \mathrm{g}$ $\square 1$ respectively by $\mathrm{Fe}_{3} \mathrm{O}_{4} / \mathrm{CS}$ NPs. The magnetic chitosan nanoparticles were prepared by a simple one- 
Table 2. Application of chitosan metallic nanoparticles in metal removing.

\begin{tabular}{lll}
\hline Chitosan/Metal & Removal metal & Reference \\
\hline Chitosan-Fe-S & $\mathrm{Cu}(\mathrm{II})$ & (Wen et al., 2015) \\
$\mathrm{CS}-\mathrm{Fe}(\mathrm{III}) \mathrm{HF}$ & $\mathrm{As}(\mathrm{V})$ & (Seyed et al., 2014) \\
$\mathrm{CS}-\mathrm{Fe}_{3} \mathrm{O}_{4}$ & $\mathrm{~Pb}(\mathrm{II})$ & ( He et al., 2019) \\
$\mathrm{CS}-\mathrm{Fe}$ & $\mathrm{Cr}(\mathrm{VI})$ & (Zimmermann et al., 2010) \\
$\mathrm{Magnetic-chitosan}$ & $\mathrm{Cr}(\mathrm{VI})$ & (Thinh et al., 2013) \\
$\mathrm{MCS}-\mathrm{Fe}$ & $\mathrm{Cr}(\mathrm{VI})$ & (Yu et al., 2013) \\
$\mathrm{CTS} / \mathrm{MMT}-\mathrm{Fe}_{3} \mathrm{O}_{4}$ & $\mathrm{Cr}(\mathrm{VI})$ & (Pina et al., 2015) \\
$\mathrm{Chitosan} / \mathrm{Fe}$ & Adsorption of rare-earth metal ions & (Liu et al., 2017) \\
$\mathrm{Fe}_{3} \mathrm{O}_{4} / \mathrm{CS} \mathrm{NPs}$ & Removal of heavy metal & (Fan et al., 2017) \\
$\mathrm{Fe}_{2} \mathrm{O}_{3} / \mathrm{chitosan}$ & lons & (Broujeni and Rouhi, 2018) \\
$\mathrm{Fe}_{3} \mathrm{O}_{4} / \mathrm{CS}$ & Adsorption of thorium (IV) ion & (Kyzas \& Deliyann 2003) \\
$\mathrm{MnFe}_{2} \mathrm{O}_{4} / \mathrm{CS}$ & settings & (Meng et al., 2015) \\
\hline
\end{tabular}

Table 3. Applications of chitosan based metallic nanoparticles as: Antimicrobial, antioxidant, anticancer etc.

\begin{tabular}{|c|c|c|}
\hline Biopolymer/metal & Bacteria & Reference \\
\hline $\begin{array}{l}\text { Chitosan cellulose/ Ag/ } \\
\mathrm{ZnO}\end{array}$ & $\begin{array}{l}\text { Escherichia coli, Pseudomonas aeruginosa, Lactobacillus } \\
\text { ferment, Enterococcus faecium, Staphylococcus aureus, } \\
\text { Bacillus licheniformis, Bacillus subtilis, Bacillus cereus, } \\
\text { Vibrio parahaemolyticus, Proteus vulgaris }\end{array}$ & $\begin{array}{l}\text { (Ghasemzadeh et al.,2016., } \\
\text { Thaya et.al, 2016) }\end{array}$ \\
\hline $\begin{array}{l}\text { Chitosan-gpoly } \\
\text { (acrylamide)/ ZnS }\end{array}$ & Escherichia coli & (Gupta et al., 2015) \\
\hline 6-O-chitosan sulfate/ $\mathrm{Au}$ & Escherichia coli & (Ehmann et al.,2015) \\
\hline Chitosan / Cu & Antibacterial activity & $\begin{array}{l}\text { (Manikandan \& } \\
\text { Sathiyabama, 2015) }\end{array}$ \\
\hline Chitosan / Fe2O3 & Antioxidant & (Ma et al., 2008) \\
\hline $\begin{array}{l}\text { Chitosan/ Ag } \\
\text { Chitosan/ ZnO }\end{array}$ & $\begin{array}{l}\text { Antibacterial activity/ Antifungal fungal activity } \\
\text { Antibacterial activity/ }\end{array}$ & $\begin{array}{l}\text { (Badawy et al., 2019) } \\
\text { (AbdElhady et al., 2012) }\end{array}$ \\
\hline Chitosan/ Ag & Anticancer activity & $\begin{array}{l}\text { (Tran et.al.,2010) (Arjunan } \\
\text { et al., 2016) }\end{array}$ \\
\hline Chitosan/ Au & DNA Carrier & $\begin{array}{l}\text { (Abrica-González et al., } \\
\text { 2019) }\end{array}$ \\
\hline Chitosan-nylon-6/Ag & $\begin{array}{l}\text { blended membranes Packaging material Escherichia coli } \\
\text { Staphylococcus aureus }\end{array}$ & (Ma et al.,2008) \\
\hline $\mathrm{CS} / \mathrm{Ag}$ & $\begin{array}{l}\text { Escherichia coli, Acinetobacter baumannii, Staphylococ- } \\
\text { cus aureus, Enterococcus faecalis, Pseudomonas aeru- } \\
\text { ginosa, and Streptococcus pneumoniae }\end{array}$ & (Meng et al., 2015) \\
\hline
\end{tabular}

step in situ co-precipitation method (Liu, et al., 2017). Magnetic particles stabilized by chitosan are being used extensively. A super paramagnetic nanoparticles (36emu/g) of (8 to 14) $\mathrm{nm}$ size were used in removal of $\mathrm{Cu}$ (II) ions up to $35.5 \mathrm{mg} / \mathrm{g}$ using the Langmuir isotherm model (Meng et al., 2015). Two chitosan derivatives were made, one by crosslinking through glutaraldehyde and second by functionalizing with crosslinking and functionalizing with magnetic nanoparticles. Second derivative was found better adsoption capacity than without magnetic nanoparticles (Kyzas and Deliyanni, 2013). Chitosan-modified Mn ferrite nanoparticles were synthesized by a one-step microwaveassisted hydrothermal method for the removal of $\mathrm{Cu}^{2+}$ ions from its stock solution in water. Results were found very attractive. Adsorption efficiency was found up to
$100 \%$ and $96.7 \%$ after $500 \mathrm{~min}$ at $6.5 \mathrm{pH}$ with starting $\mathrm{Cu}^{2+}$ ions concentration (50 mg/L and $100 \mathrm{mg} / \mathrm{L}$ ). Langmuir isotherm models were found fit for adsorption data. Langmuir adsorption equilibrium constant, a maximum adsorption capacity, rate constants were also determined by using adsorption data. It was found in good agreement with pseudo second order model (Meng et al., 2015) (Table 2).

\section{Antibacterial activity}

Chitosan stabilized metallic nanoparticles have huge attention of scientist as chitosan itself shows antimicrobial activity alone and when metal nanoparticles are attached with it. It shows an excellent antimicrobial property. Scientists have suggested many mechanisms for antimicrobial activity of chitosan. One of the mecha- 
nisms says that chitosan is very good chelating agent and when it comes in contact of the microbial cell; it binds to the metals of the cell. So cell function is stopped and bacteria dyes. The chitosan-CMC Ag Nanocomposite demonstrates good antimicrobial activity against Escherichia coli, Staphylococcus aurous and Pseudomonas aeruginosa (Ghasemzadeh, et al., 2016, Thaya et al., 2016). Chitosan stabilized Ag nanoparticles have been found antimicrobial again, both grampositive (Bacillus sp. and Staphylococcus) and gramnegative (Pseudomonas) bacterial (Meng et al., 2015, $\mathrm{Ma}$, et al., 2008). A chitosan stabilized $\mathrm{Cu}$ nanoparticles have been prepared to see the antimicrobial activity against gram-positive and gram-negative bacteria. Results show that chitosan stabilized $\mathrm{Cu}$ nanoparticles were more effective in gram-negative bacteria than gram-positive. This may be due to differences in cell wall composition (Manikandan et al.,2015) (Table 3).

\section{Conclusion}

Chitosan stabilized metallic nanoparticles appear to be a suitable polymeric complex for many applications viz. antimicrobial activity, adsorptions (purification), biosensing, environmental remediation, catalytic activity, antioxidant activity, food packaging preservation, drug delivery, bio imaging anti-cancer activity and wound healing property. Chitosan is not only responsible for reducing, stabilizing and capping nanoparticles, but it is also responsible for the size and shape of nanoparticles. Less work is done so far about the effect of chitosan on the shape and size of nanoparticles. Chitosan has been found responsible for deciding the size and shape of metallic nanoparticles. Even the variation in molecular weight can affect the size of metallic nanoparticles. It is important to notice that chitosan is responsible for size and shape deciding, reaction time, type of method, sonication time, temperature of reaction, etc. This review will be beneficial for those scientists who are working on optimization condition of metallic nanoparticles stabilized by chitosan and their applications.

\section{Conflict of interest}

The authors declare that they have no conflict of interest.

\section{REFERENCES}

1. AbdElhady, M. M. (2012). Preparation and characterization of chitosan/zinc oxide nanoparticles for imparting antimicrobial and UV protection to cotton fabric. International Journal of Carbohydrate Chemistry, 2012, 840591. https://doi.org/10.1155/2012/840591
2. Abrica-González, P., Zamora-Justo, J.A., Sotelo-López, A. G. R. Vázquez-Martínez, J. A. Balderas-López, A. MuñozDiosdado \& M. Ibáñez-Hernández (2019). Gold nanoparticles with chitosan, $\mathrm{N}$-acylated chitosan, and chitosan oligosaccharide as DNA carriers. Nanoscale Research Letters 14, 258.

3. Ahmad M.B., Tay, M.Y., Shameli, K., Hussein, M.Z. \& Lim, J.J. (2011). Green synthesis and characterization of silver/chitosan/polyethylene glycol nanocomposites without any reducing agent. International Journal of Molecular Sciences, 12 (8), 4872-4884. -Doi: 10.3390/ ijms 12084872

4. Akbari-Sharbaf, A., Ezugwu, S., Shafiq, M., Cottam M., \& Fanchini, G. (2015). Doping graphene thin films with metallic nanoparticles: Experiment and theory. Carbon, 95, 199-207. https://doi.org/10.1016/j.carbon.2015.08.021

5. Ali, F., Khan, S. B., Kamal, T., Alamry, K. A., \& Asiri, A. M. (2018). Chitosan-titanium oxide fibers supported zerovalent nanoparticles: highly efficient and easily retrievable catalyst for the removal of organic pollutants. Scientific Reports, 8(1), 1-18. DOI:10.1038/s41598-018-24311-4

6. Al-Sayed A. Al-Sherbini, Hala E.A. Ghannam, Gamal M.A. El-Ghanam, Amr. A. El Ella, Ahmed M. Youssef. (2019). Utilization of chitosan/Ag bionanocomposites as ecofriendly photocatalytic reactor for Bactericidal effect and heavy metals removal, Heliyon, 5 (6), e01980, https:// doi.org/10.1016/j.heliyon.2019.e01980

7. Arjunan, N., Kumari, H.L.J., Singaravelu, C.M., Kandasamy, R. \& Kandasamy, J. (2016). Physicochemical investigations of biogenic chitosan-silver nanocomposite as antimicrobial and anticancer agent. Int. J. Biol. Macromol. 92, 77-87. 10.1016/j.ijbiomac.2016.07.003.

8. Badawy, M. E., Lotfy, T. M., \& Shawir, S. M. (2019). Preparation and antibacterial activity of chitosan-silver nanoparticles for application in preservation of minced meat. Bulletin of the National Research Centre, 43(1), 83.

9. Baran, T. (2020). Highly Active and Robust Palladium Nanoparticles Immobilized On Biodegradable Microcapsules Containing Chitosan-Guar Gum Composite for Synthesis of Biaryl Compounds. Konya MühendislikBilimleri Dergisi, 8(1), 113-121. DOI:10.36306/konjes.698694

10. Broujeni B.R., Nilchi, A., Hassani, A.H. \& Saberi, R. (2018). Preparation and characterization of chitosan/ $\mathrm{Fe} 2 \mathrm{O} 3$ nano composite for the adsorption of thorium (IV) ion from aqueous solution. Water Science and Technology, 78(3), 708-720. https://doi.org/10.2166/wst.2018.343

11. Chattopadhyay, S., Dash, S. K., Mahapatra, S. K., Tripathy, S., Ghosh, T., Das, B., Panchanan P. \& Roy, S. (2014). Chitosan-modified cobalt oxide nanoparticles stimulate TNF- $\alpha$-mediated apoptosis in human leukemic cells. JBIC Journal of Biological Inorganic Chemistry, 19 (3), 399-414. https://doi.org/10.1007/s00775-013-1085-2

12. Choudhary, R. C., Kumaraswamy, R. V., Kumari, S., Sharma, S. S., Pal, A., Raliya, R. and Saharan, V (2019). Zinc encapsulated chitosan nanoparticle to promote maize crop yield. International Journal of Biological Macromolecules, 127, 126-135.

13. He, Y., Wu, P., Xiao, W., Li, G., Yi, J., He, Y. \& Duan, Y. (2019). Efficient removal of $\mathrm{Pb}$ (II) from aqueous solution by a novel ion imprinted magnetic biosorbent: Adsorption kinetics and mechanisms. PloSOne, 14(3). https:// doi.org/10.1371/journal.pone.0213377 
14. Dung, D.T.K., Hai,T.H., Phuc, L.H., Long, B.D., Vinh L.K. \& Truc P.N. (2009). Preparation and characterization of magnetic nanoparticles with chitosan coating. Journal of Physics: Conference Series. IOP Publishing, 187 (1), 012036.

15. Ehmann, H.M.A., Breitwieser, D., Winter, S., Gspan, C., Koraimann, G., Maver, U., Sega, M., Köstler, S., StanaKleinschek, K., Spirk, S. \& Ribitsch, V. (2015). Gold nanoparticles in the engineering of antibacterial andanticoagulant surfaces. Carbohydrate Polymer, 117, 34-42. https:// doi.org/10.1016/j.carbpol.2014.08.116

16. Fan, H. L., Zhou, S. F., Jiao, W. Z., Qi, G. S., \& Liu, Y. Z. (2017). Removal of heavy metal ions by magnetic chitosan nanoparticles prepared continuously via high-gravity eactive precipitation method. Carbohydrate polymers, 174, 2017, 1192-1200. https://doi.org/10.1016/ j.carbpol.2017.07.050

17. Ghasemzadeh, H., Mahboubi, A., Karimi, K. \& Hassani, S. (2016). Full polysaccharide chitosan-CMC membrane and silver nanocomposite: Synthesis, characterization, and antibacterial behaviors. Polymers Advanced Technology, 27, 1204-1210. https://doi.org/10.1002/pat.3785

18. Gupta, D., Singh, D., Kothiyal, N.C., Saini, A.K., Singh, V.P. \& Pathania, D. (2015). Synthesis of chitosan-gpoly (acrylamide)/ZnS nanocomposite for controlled drug delivery and antimicrobial activity. Intenational Journal of Biologicla Macromolecules. 74, 547-557. https:// doi.org/10.1016/j.ijbiomac.2015.01.008

19. Guzman, J., Saucedo, I., Navarro, R., Revilla, J. \& Guibal, E. (2002). Vanadium interactions with chitosan: Influence of polymer protonation and metal speciation. Langmuir, 18 (5), 1567-1573. https://doi.org/10.1021/la010802n

20. Honary, S., K Ghajar, K., Khazaeli, P. \& Shalchian, P. (2011). Preparation, Characterization and Antibacterial Properties of Silver-Chitosan Nanocomposites Using Different Molecular Weight Grades of Chitosan, Tropical Journal of Pharmaceutical Research, 10 (1): 69-74. DOI: 10.4314/tjpr.v10i1.66543

21. Huang, X., Jain, P.K., El-Sayed, I.H., El-Sayed, M.A. (2008). Plasmonic photothermal therapy (PPTT) using gold nanoparticles. Lasers in Medical Science, 23, 217228. https://doi.org/10.1007/s10103-007-0470-x

22. Huo, M., Zhang, Y., Zhou, J., Zou, A., Yu, D., Wu, Y., Li, J. \& Li, H. (2010). Synthesis and characterization of low toxic amphiphilic chitosan derivatives and their application as micelle carrier for antitumor drug. International Journal of Pharmaceutics, 394(1-2), 162-173. https://doi.or g/10.1016/j.ijpharm.2010.05.001

23. Javed, R., Zia, M., Naz, S., Aisida, S.O., Ain, N.A. \& Ao, Q. (2020). Role of capping agents in the application of nanoparticles in biomedicine and environmental remediation: recent trends and future prospects. Journal of Nanobiotechnology, 18, 172. https://doi.org/10.1186/s12951020-00704-4

24. Kamal, T., Khan, S.B., \& Asiri, A.M. (2016). Nickel nanoparticles-chitosan composite coated cellulose filter paper: an efficient and easily recoverable dip-catalyst for pollutants degradation. Environmental Pollution, 218, 625-633. https://doi.org/10.1016/j.envpol.2016.07.046

25. Khedri B., Shahanipour, K., Fatahian, S., \& Jafary F. (2018). Preparation of chitosan-coated Fe3O4 nanoparticles and assessment of their effects on enzymatic antioxi- dant system as well as high-density lipoprotein/lowdensity lipoprotein lipoproteins on wistar rat. Biomedical and Biotechnology Research Journal (BBRJ), 2(1), 68-73. DOI: 10.4103/bbrj.bbrj_98_17

26. Kumar S., Bhushan P., Bhattacharya S. (2018) Positively Charged Silver Nanoparticles as Labels for PaperBased Colorimetric Detection of Heparin. In: Ibrahim F., Usman J., Ahmad M., Hamzah N., Teh S. (eds) 2nd International Conference for Innovation in Biomedical Engineering and Life Sciences. ICIBEL 2017. IFMBE Proceedings, vol 67. Springer, Singapore. https:// doi.org/10.1007/978-981-10-7554-4_41.

27. Kyzas, G.Z. \& Deliyanni, E.A. (2013). Mercury (II) removal with modified magnetic chitosan adsobents. Molecules, 18 (6), 6193 - 6214.https://doi.org/10.3390/molecules 18066 193

28. León, Y., Cárdenas, G. \& Arias, M. (2017). Synthesis and characterizations of metallic nanoparticles in chitosan by chemical reduction. Journal of the Chilean Chemical Society, 62(4), 3760-3764. http://dx.doi.org/10.4067/s07179707017000403760

29. Lin, Y.C., Tan, F.J., Marra, K.G., Jan, S.S. \& Liu, D.C. (2009). Synthesis and characterization of collagen/ hyaluronan/chitosan compositesponges for potential biomedical applications. ActaBiomaterialia, 5 (7), 25912600. https://doi.org/10.1016/j.actbio.2009.03.038

30. Liu, E., Zheng, X., Xu, X., Zhang, F., Liu, E., Wang, Y. \& Yan, Y.(2017). Preparation of diethylenetriamine - modified magnetic chitosan nanoparticles for adsorption of rare -earth metal ions. New Journal of Chemistry, 41 (15), 7739-7750. https://pubs.rsc.org/en/content/articlelandin g/2017/nj/c7nj02177a\#!divAbstract

31. Liu, X., Cheng, H. \& Cui. P. (2014). Catalysis by silver nanoparticles/porous silicon for the reduction of nitroaromatics in the presence of sodium borohydride. Applied Surface Science. 292, 695-701.

32. Lupusoru, R.V., Simion, L., Sandu, I., Pricop, D.A., Chiriac, A.P., Poroch, V. (2017). Aging Study of Gold Nanoparticles Functionalized with Chitosan in Aqueous Solutions. Revista De Chimie. 2017, 68(10), 2385-2388. DOI:10.37358/RC.17.10.5891

33. Ma Y., Zhou, T., \& Zhao, C. (2008). Preparation of chitosan-nylon- 6 blended membranes containing silver ions as antibacterial materials. Carbohydrate research, 343(2), 230-237. https://doi.org/10.1016/j.carres.2007.11.006

34. Manikandan, A., \& Sathiyabama, M. (2015). Green synthesis of copper-chitosan nanoparticles and study of its antibacterial activity. Journal of Nanomedicine \& Nanotechnology, 6(1), 1-5. DOI: 10.4172/2157-7439.1000251

35. Marpu, S. B., \& Benton, E. N. (2018). Shining light on chitosan: a review on the usage of chitosan for photonics and nanomaterials research. International Journal of Molecular Sciences, 19(6), 1795. DOI: 10.3390/ ijms19061795.

36. Meng, Y., Chen, D., Sun, Y., Jiao, D., Zeng, D., \& Liu, Z. (2015). Adsorption of $\mathrm{Cu}^{2+}$ ions using chitosan-modified magnetic Mn ferrite nanoparticles synthesized by microwave-assisted hydrothermal method. Applied Surface Science, 324, 745-750.

37. Misra, N., Rapolu, M., Rao, S., Varshney, L. \& Kumar, V. (2016). Nonlinear optical studies of inorganic nanoparticles -polymer nanocomposite coatings fabricated by elec- 
tron beam curing. Optics \& Laser Technology, 79, 24-31. https://doi.org/10.1016/j.optlastec.2015.11.004

38. Pina, S., Oliveira, J. M. \& Reis, R. L. (2015). Natural based nanocomposites for bone tissue engineering and regenerative medicine: A review. Advanced Materials, 27 (7), 1143-1169. https://doi.org/10.1002/adma.20140 3354

39. Potara, M., Maniu, D. \& Astilean, S. (2009). The Synthesis of Biocompatible and SERS-Active Gold Nanoparticles using Chitosan. Nanotechnology, 20, 1-7. DOI: 10.10 88/0957-4484/20/31/315602

40. Sannegowda, K., Shambhulinga, A., Manjunatha, N., Imadadulla, M. \& Hojamberdiev, M. (2015). Porphyrin macrocycle-stabilized gold and silver nanoparticles and their application in catalysis of hydrogen peroxide. Dyes and Pigments, 120, 155-160. https://doi.org/10.1016/ j.dyepig.2015.04.002

41. Sanpui, P., Murugadoss, A., DurgaPrasad, P.V., Sankar Ghosh, S., Chattopadhyay, A., (2008). The antibacterial properties of a novel chitosan-Ag-nanoparticle composite. International Journal of Food Microbiology, 124(2), 142-146. https://doi.org/10.1016/j.ijfoodmicro.2008.03.004

42. Santos, H.H., Demarchi, C.A., Rodrigues, R.C., Greneche J.M., Nedelko, N., Waniewska, A.S. (2011). Adsorption of As (III) on chitosan-Fe-crosslinked complex (Ch-Fe). Chemosphere, 82(2), 278-283. https:// doi.org/10.1016/j.chemosphere.2010.09.033

43. Sengupta, S., Eavarone, D., Capila, I., Zhao, G., Watson, N., Kiziltepe, T. Sasisekharan, R. (2005). Temporal targeting of tumour cells and neovasculature with a nanoscale delivery system. Nature, 436, 568-572.

44. Seyed Dorraji, M. S., Mirmohseni, A., Tasselli, F., Criscuoli, A., Carraro, M., Gross, S. \& Figoli, A. (2014). Journal of Polymer Research, 21(4), 399-412.

45. Tahir, S. K., Yousaf, M. S., Ahmad, S., Shahzad, M. K., Khan, A. F., Raza, M. \& Rehman, H. (2019). Effects of Chromium-Loaded Chitosan Nanoparticles on the Intestinal Electrophysiological Indices and Glucose Transporters in Broilers. Animals, 9(10), 819. doi: 10.3390/ani9100819

46. Thaya, R., Malaikozhundan, B., Vijayakumar, S., Sivakamavalli, J., Jeyasekar, R., Shanthi, S., Vaseeharan, B., Ramasamy, P. \& Sonawane, A. (2016). Chitosan coated $\mathrm{Ag} / \mathrm{ZnO}$ nanocomposite and their antibiofilm, antifungal and cytotoxic effects on murine macrophages. Microbial Pathogenesis. 100, 124-132. https://doi.org/10.1016/ j.micpath.2016.09.010

47. Thinh, N.N., Hanh, P.T., Ha, L.T.T., Anh, L.N., Hoang, T.V., Hoang, V.D., Dang, L.H., Khoi, N.V. \& Lam. T.D. (2013). Material Science and Engineering C-Material, 33 1214-1218.

48. Thirumavalavan, M., Yang, F.M. \& Lee, J.F. (2013). Investigation of preparation conditions and photocatalytic efficiency of nano $\mathrm{ZnO}$ using different polysaccharides. Environmental Science and Pollution Research, 20, 56545664. https://doi.org/10.1007/s11356-013-1575-3

49. Tran, H.V., Tran, L.D., Ba, C.T., Vu, H.D., Nguyen, T.N., Pham, D.G. \& Nguyen, P.X. (2010). Synthesis, characteri- zation, antibacterial and antiproliferative activities of monodisperse chitosan- based silver nanoparticles. Colloids and Surfaces A: Physicochemical and Engineering Aspects, 360(1-3), 32-40. https://doi.org/10.1016/j.cols urfa.2010.02.007

50. Vo, K.D.N., Guillon, E., Dupont, L., Kowandy, C. \& Coqueret, X. (2014). Influence of Au (III) interactions with chitosan on gold nanoparticle formation. The Journal of Physical Chemistry C, 118(8), 4465-4474. https:// doi.org/10.1021/jp4112316

51. Wang, C., Gao, X., Chen, Z., Chen, Y. \& Chen H. (2017a). Preparation, characterization and application of polysaccharide-based metallic nanoparticles: a review. Polymers, 9(12), 689. doi: 10.3390/polym9120689

52. Wang, Y. Kong, Q., Ding, B., Chen, Y., Yan, X., Wang, S., Chen, F., You, J. \& Li, C. (2017b). Bio inspired catechetic activation of marine chitin for immobilization of $\mathrm{Ag}$ nanoparticles as recyclable pollutant nanocatalysts. J. Colloid Interface Sci. 2017, 505, 220-22. https://doi.org/10.1016/ j.jcis.2017.05.099

53. Wen, Y., Ma, J., Chen, J., Shen, C., Li, H. \& Liu, W. (2015). Carbonaceous sulfur-containing chitosan-Fe(III): A novel adsorbent for efficient removal of copper (II) from water, Chemical Engineering Journal, 259, 372-380.

54. Worthington, K.L.S., Adamcakova-Dodd, A., Wongrakpanich, A., Mudunkotuwa, I.A., Mapuskar, K.A., Joshi, V.B., Allan Guymon, C., Spitz, D.R., Grassian, V.H. Thorne, P.S. (2013). Chitosan coating of copper nanoparticles reduces in vitro toxicity and increases inflammation in the lung. Nanotechnology, 24, 395101. doi: 10.1088/0957-4484/24/39/395101.

55. Younes, I., \& Rinaudo, M. (2015). Chitin and chitosan preparation from marine sources. Structure, properties and applications. Marine drugs, 13(3), 1133-1174. DOI: 10.3390/md13031133

56. Yu, Z., Zhang, X. \& Huang, Y. (2013). Magnetic Chitosan -Iron(III) Hydrogel as a Fast and Reusable Adsorbent for Chromium(VI) Removal. Industrial and Engineering Chemistry Research, 52, 11956-11966.

57. Zang, L., Quu, J., Wu, X., Zhang, W., Sakai, E. \& Wei, Y. (2014). Preparation of magnetic chitosan nanoparticles as support for cellulase immobilization. Industrial \& engineering Chemistry Research 53(9), 3448-3454. https:// doi.org/10.1021/ie404072s

58. Zeinali, S., Nasirimoghaddam S., \& Sabbaghi, S. (2016). Investigation of the synthesis of chitosan coated iron oxide nanoparticles under Different Experimental Conditions. Interational Journal of Nanoscience and Nanotechnology, 12 (3), 183-190. http://www.ijnnonline.net/article_2173 1.html

59. Zimmermann A.C., Mecabo, A., Fagundes, T. \& Rodrigues, C.A. (2010). Adsorption of $\mathrm{Cr}(\mathrm{VI})$ using $\mathrm{Fe}-$ crosslinked chitosan complex (Ch-Fe), Journal of Hazardous Materials, 179,192-196. https://doi.org/10.1016/j.jhaz mat.2010.02.078 